\title{
The Use of Technology for Vocabulary Instruction in EFL Classrooms: Support and Challenges
}

\author{
Istanti Hermagustiana ${ }^{1}$, Desy Rusmawaty ${ }^{2}$ \\ ${ }^{1,2}$ Faculty of Teacher Training and Education, Mulawarman University, Samarinda, East Kalimantan, Indonesia \\ istanti_hermagustiana@yahoo.com,desyrusmawaty@yahoo.com
}

\begin{abstract}
Technology is believed and proven to provide support for teaching and learning in the classroom. Nevertheless, it also turns out into problems when the teachers are not ready for its use. This study aims to investigate the support technology offers to EFL teachers in their teaching practice and figure out some challenges they face when using technology for teaching vocabulary. By using semi-structured interview and classroom observation, this multiple case study revealed that technology supported the EFL teachers through several ways, such as the use of digital dictionaries, internet, and Powerpoint presentation as teaching media. In addition, some challenges which appeared when the teachers attempted to use technology in the classroom were scrutinized.
\end{abstract}

Keywords-technology, EFL classrooms, teaching media, vocabulary teaching

\section{INTRODUCTION}

Technology has been a crucial developing part in people's lives since its rapid worldwide expansion covers different areas including education. Currently, technology has been regarded as the centerpiece in education [1]. The technology application in EFL classrooms in the 20th century comprised the use of the radio and television, film, VHS, VCR, and cassettes. However, the technology developed at the end of the century including digital CD players, projectors of slides, DVDs and computers. Computers opened the doors to multimedia tools also known as CALT (Computer Assistance Language Teaching) [55]. In short, technology has brought technological tools to contribute to education and facilitate the teaching/learning process [49].

Teachers are nowadays taking advantages of technological tools to improve students' language skills in EFL classrooms. Even though technology is not a panacea for education, its practical functions can appropriately be used as a complement in the classroom practice [49]. Interestingly, researchers have found that technology helps students get involved in the language learning process. Accordingly, it gives them a chance to see the real world by using authentic material and it is possible for teachers to make a more interactive class by using, for example, online English exercises. Moreover, technology can offer an active learning environment for language learners. For instance, some teachers may ask their students to make a video about performing action verbs, dramatize a short tale, etc. Furthermore, it promotes positive attitude toward learning, saving time for both teachers and students [54].
This current study focuses on the integration of technology in the teaching of English vocabulary in the classroom context. The rationale of carrying out this research is due to the fact that most of research on technology in education primarily emphasize the benefits of practical use of technological tools for teaching and learning English [24][53] [5][46]. To fill this gap, this study attempts to figure out the EFL teachers' cognition about the technology support and challenges the teachers face with the technology in their teaching practice. Therefore, the researchers formulate the following questions:

1. How does the technology support the EFL teachers in their vocabulary teaching practice?

2. What challenges do the EFL teachers face when using technology for teaching vocabulary?

\section{LITERATURE REVIEW}

\section{A. Technology in Teaching}

Due to the challenging situation in teaching a new language, EFL teachers need to involve their students by using different methods and techniques in the teaching and learning process. During this process, the teachers need to develop a positive motivation, encouragement, and attitudes in each student toward the learning process [26]. One of the factors that help teachers develop those aspects in students refers to technology. Technology is believed to affect the students' attitude positively in the learning process [49].

What's more, using technology, for example, may give students the chance to be in touch with the real world and it can be motivating for them. In addition, using technology as an aid helps students to be active, eager and involved in classes due to the interest that the use of technology produces [33]. There is no doubt that using computers and the different kinds of technological tools affect students' behavior in a positive way.

\section{B. Integrating Technology in Vocabulary Teaching}

Although the pervasiveness of ICTs in all aspects of 21stcentury life is quite clear and well accepted, it is less clear how teachers might successfully integrate technology into literacy instruction and specifically vocabulary instruction. Improving students' vocabulary is an area of urgent need if we are to develop the advanced literacy levels required for 
success in school and beyond [10][29]. Vocabulary is also an area where teachers are asking for guidance on instructional approaches, strategies, and materials [9]. We believe that digital tools and media are available in most schools that teachers could harness now to improve vocabulary learning, tools that capture the interest of students and that provide scaffolds and contexts in which to learn with, and about, words more profitably.

Direct vocabulary instruction is essential, but research indicates that students with well-developed vocabulary learn many more words indirectly through reading than from instruction [20]. Two strategies that encourage children to read widely and deeply are to provide an array of reading materials that capitalize on their interests and to set aside time for reading during the school day and at home [21]. Conversations about their reading with adults and peers also strengthen students' word learning [11]. Whether directly teaching vocabulary and word learning strategies, or increasing students' volume of reading, an important research-based principle that applies across the board is to promote a lively interest in words through student expression and participation in a learning community that enjoys playing with words, builds on individual interests as well as curriculum needs, and emphasizes self-efficacy in word learning [8][29].

Reference [21] proposes a number of ways which vocabulary can be integrated in vocabulary teaching and learning. Those include: (1) learn from visual displays of word relationships within text, (2) connect fun and learning with online vocabulary games, (3) have students use media to express vocabulary knowledge, (4) support reading and word learning with just-in-time vocabulary reference support, (5) use language translators to provide just-in-time help for English language learners (ELLs), (6) increase reading volume by reading digital text, and (7) increase reading volume by listening to digital text with a text-to-speech tool and audio books.

\section{Methodology}

\section{A. Design.}

This study focuses on an exploratory investigation of the use of technology used by EFL teachers' cognitions and the implementation of vocabulary instruction in Indonesian classroom context. Therefore, a qualitative data collection method was employed for this study.

\section{B. Research Subjects}

The researchers set some criteria to select the EFL teachers as the subjects of this study. First, the teacher participants should be those who taught grade 11 at secondary school. Second, the teachers should use the most current curriculum, which is Kurikulum 2013 (K-13), for the lesson plans. The consideration of selecting this curriculum since it is the most recently used by most of Indonesian schools, including the schools selected in this present study, due to the Government policy. Third, the selected teachers should have, at least, 5 year experience as English teachers since it is expected that the teachers have held considerable cognitions about vocabulary instruction during pre- and in-service teaching programs which would be reflected into the instructional practices. Fourth, the teacher participants were those selected after some informal consultation with headmasters of the schools as well as their colleagues. From the abovementioned criteria, four EFL teachers were determined and subsequently named as $\mathrm{T} 1, \mathrm{~T} 2, \mathrm{~T} 3$, and $\mathrm{T} 4$.

\section{Data Collection Procedures}

The teachers were interviewed separately and the interviews were semi-structured to let the interviewees express what they knew, thought, and believed concerning vocabulary instruction in their classrooms. This study employed semistructured interviews, which were guided by a list of interview questions and designed to put interviewees at ease and allow them to express themselves [36]. In the study, the researcher observed 14 meetings (i.e. T1: 4 meetings, T2: 3 meetings, T3: 4 meetings, and T4: 3 meetings). The different number of meetings observed for each participant due to their personal preference and agreement, and the limited time before the students had their semester examination.

\section{Data Analysis Techniques}

The data analysis in this study was based on [40] interactive model. It starts from data collection, followed by data reduction, data display, and ends up with conclusion. For the main research instruments, interviews and classroom observation field notes, all utterances were transcribed and inductively analyzed to view teachers' cognitions and identify the teaching practices of vocabulary applied by the teachers in an EFL classroom for several meetings.

\section{FINDINGS}

The finding section attempts to answer the research questions based on the obtained data from interview and observation.

\section{A. How does the technology support EFL teachers in their vocabulary teaching practice?}

The abovementioned question revealed two dimensions of technology in vocabulary teaching. The first dimension refers to the kinds of technological tools for the EFL teachers to enhance the students' vocabulary through technology. The second dimension provides the three types of technologybased teaching aids used in the participants' classrooms. Three kinds of support were found out to be used by the participants in their practice. First, digital dictionary was used to help both teachers and students define word meanings easily and fast. Therefore, its existence supports vocabulary teaching in the classroom. T4 illuminated, "If the students and I are confused with the meaning, we open the digital dictionary and we can find many words there" (T4, initial interview). Moreover, T4 insisted that she could not prohibit the students from consulting dictionaries since some of the students brought their digital dictionaries into the classroom. She explained,

"When the students read a text, they underline some difficult or unknown words from the reading texts, and I ask them to predict the meaning. Usually predict the 
meaning from context is difficult when they don't know the words around. So it is getting more difficult to understand the meaning. But some students... they bring digital dictionary, they use it to get the meaning. And then they share the meaning with the others" (T4, initial interview).

Aligned with T4, T1 did not let her students leave their dictionary at home in spite of its time-consuming tendency. It was still considered helpful in defining a word meaning. She declared, "We (teachers) recommend that the students look up the dictionary for the new vocabulary they meet" (T1, follow up interview). She added, "If students find the difficulties, please look up the dictionary, it will increase their vocabulary" (T1, follow up interview).

In addition to digital dictionaries applied to help support vocabulary instruction in the classroom, the teachers believed that current technology is nowadays utilized by the students to do many things, such as internet could be useful for the students to improve their English vocabulary. T3 explained,

"But now the media... all sophisticated media support them...equip them every day...like smartphone. They can learn new words from their hand phones or from internet. I'm sure they find out some English word from the media, like social media... Facebook, twitter... Usually the social media like Facebook use English... twitter also. They also can see their friends or other people, maybe, from abroad when giving comments using English. In social media, they are free to write in English, they don't have to care about grammar. I won't check their grammar in socmed. (Laughing)" (T3, follow up interview).

Second, the technology application, such as internet, could develop into a problem if teachers were not careful to control its use in the classrooms. T1 found it a challenge in her teaching practice as she affirmed,

"Use of internet in the classroom is a challenge for teachers. For example, when I asked them to write a procedure text, I had to think about the recipe that might not be available in the internet, or it is difficult for them to search on it. Because if it is just a common recipe, the recipe that can be easily found in the internet, so they could copy it" (T1, follow up interview).

The teacher's assumption on the use of internet was seen from her observed teaching practice. In the fourth observation, T1 focused on Procedure texts. This lesson was initiated by her to assign the students to write their own procedure texts (i.e. recipes) and to present them in the classroom. During the process of creating the procedure texts, it was found out that most of the students made the most use of internet. They even just copied what was written on the internet to their work (T1, Obs4). This resulted in T1's concern on the plagiarism habit that could affect the development of the students' English skills.

Despite the less control over internet, T2 still had a trust on internet as a source of vocabulary teaching from which she frequently searched for additional and relevant teaching materials. She explained, "I usually look for the teaching materials not only from the textbook but also from other sources, for example, internet." (T2, initial interview). Based on a captured episode of her teaching practice, T2 provided some pictures of food, animals, electronic devices, etc, through Power point presentation when she started a lesson about Report texts. The collection of pictures she exhibited was obtained through internet as they were not available in the English textbook used at school (T2, Obs3).

Third, in addition to some technological devices which were utilized to support the students' vocabulary learning, the EFL teacher participants were also responsible for giving instruction through media of technology. The most popular technology used by the participants was the use of Power Point for instructional material presentation. The participants (T1 and T4) believed that Power Point presentation helped them save time while giving some explanation with regard to the discussed materials. It was clarified by T1 who said,

"I believe that Ppt presentation is the best idea to present something... like pictures... so that the students can learn...or guess may be... what they see on the slide. It also can help me with saving time because I don't have to write, for example, the explanation of the material on whiteboard. So I think it is very important for me to use Ppt in the classroom." (T1, follow up interview).

Moreover, that technology supported vocabulary teaching in the participants' classroom practices. They affirmed that students' vocabulary knowledge could be stimulated through the use of power point presentation. Two participants (T2 and T3) employed the presentation of Power point for vocabulary instruction through pictures or videos. They declared that pictures could enhance their students' vocabulary enrichment as pictures had visualization which interested the students to learn something from the power point. T3 explained,

"We can show some pictures to the students through Ppt. By doing so, they can learn the names of the things on the pictures, for example. Or I can have vocabulary games with Ppt, for example crossword puzzle. It is impossible to write on whiteboard, so I think Ppt is very important to improve my teaching." (T3, follow up interview).

All of the views shared by the participants were seen from their teaching performance in every meeting observed that all of them handled the materials by using Power point presentation. Therefore, all of the teachers always brought their own laptops to the classroom and utilized the laptop along with LCD from the beginning of the lessons. In the observation, all of the participants mostly presented the materials which entailed the definition of the main concepts (e.g. invitation letter, figures of speech, etc.) the examples pertaining to the key concepts (e.g. T1, Obs3; T4, Obs1).

Moreover, some tasks like vocabulary exercise or reading comprehension questions were also presented through Power point presentation (e.g. T4, Obs1). Furthermore, the teachers deployed visual support, such as pictures, to elicit some information or ideas from the students and to confirm their prior knowledge concerning the discussed materials (e.g. T2, Obs3; T3, Obs3). However, there was only one teacher (T2) who incorporated the use of video in her teaching practice. As a consequence, the video was used to help the students 
improve their listening ability as well their vocabulary knowledge (T2, Obs2).

The second dimension on the use of technology in teaching vocabulary pertains to the types of teaching aids for students' vocabulary enhancement. The first observed teaching pattern in the participants' classroom was the use of visual aids. In addition to providing the students with some visual information to elicit in the beginning of a lesson, this strategy consistently used in while-teaching phase. For example, T2 employed the use of PowerPoint (Ppt) presentation in her classroom for the lesson of Invitation Letters. Her Ppt presentation included the definition of Invitation Letters, followed by the examples of the letters, and the parts of an invitation letter. The exposure from Ppt presentation was meant to help the students clearly see what T2 said during the explanation. By doing this strategy, both students' listening and reading skills were emphasized.

Furthermore, the second type of strategy with regard to the technology was the use of audio teaching aid, such as a monologue, a dialogue, or a song recording. For instance, T4 assigned her students to accomplish a fill-in-the-blank exercise by listening to a song. The students had to fill the missing lyrics using the words they heard from the song. After the listening practice was accomplished, the teacher discussed the answers. Another example of the use of audio teaching aid in enhancing students' vocabulary was from T3's classroom. In one of her observed teaching episodes, at the end of the meeting, she gave the students a listening practice which required their understanding towards some dialogues spoken by two speakers. Fortunately, this strategy was supported by the use of pictures from the textbook to be matched with the dialogues in order to help the students find out the content of each dialogue.

Third, the last type of the use of teaching aids observed from the participants' classroom practices was the use of audio-visual teaching aid, such as a video. This strategy was observed to be used by one participant, T2. In the while teaching phase, T2 decided on giving the students listening practice. In the first practice, they would listen to someone describing procedures of how to make a pie. Therefore, the focus of this activity was on students' listening ability and their familiarity of spoken words. Once the students finished the activity, the teacher had a discussion to ensure whether the students successfully wrote a complete procedure of making a pie along with its ingredients. After that, the recording was played once more accompanied by the visualization showing the speaker, the ingredients, and all cooking tools used to make a pie. The teacher used different treatments in listening practice to find out whether the students understood the recording differently. She confirmed,

"That was actually my experiment. I used a video since video provided a lot of visual support for listening practice, but I made it a little bit challenging. I wanted to see how much they could understand before and after seeing the video. The result was surprising, very different. Without the visual, only sound, they only understood $30 \%$ of what's happening in the video, while visual support made them understand around 70-80\%" (T2, follow up interview).

\section{B. What challenges do the EFL teachers face when using technology for teaching vocabulary?}

In answering this question, three challenges were revealed. The first challenge was related to the teachers' lack of advanced technological competence. Despite the participants' claims on the usefulness of PowerPoint presentation (Ppt) in their teaching practices, some weaknesses pertaining to the use of technology appeared in this current study. The display of their Ppt looked very simple and plain. Moreover, the absence of moving pictures or images in the slides showed the limited knowledge on using advanced technology to attract students' attention toward the learning materials. This limitation was observed in all participants' teaching practice.

Second, the difficulty in using technology for teaching vocabulary resulted from less attention from school, for example: the lack of teaching facilities, such as language laboratory, which function to provide the students with multimedia in English teaching and learning. During the observations, the four EFL teachers never used language labs in their schools in language class hours. Some reasons given were concerned about some technical issues concerning electricity and laboratory impairment. One of the participants reported,

"I seldom took my students to the language laboratory due to the time efficiency. It took time to take them there. It means that I would spend time not in the language laboratory, but on my way there. Besides, there are some facilities which can only be partially utilized. For example, insufficient electricity power if the language laboratory is used all the time. Hence, I preferred using the simple one, such as a speaker in the classroom as well as my laptop and LCD. That's it (T3, follow up interview).

Consequently, limited teaching media had to be utilized in the classroom and teachers' creativity was exceptionally required. The participant clarified,

"Our school language laboratory was not in good condition so at the moment we don't have that facility. As a consequence, we, the teachers, must be creative in any way. For example, I use a tape recorder or a laptop for listening practices. So, when it cannot be done in the laboratory, I can do it in the classroom. Or, I can play a video for teaching through my laptop" (T2, follow up interview).

Third, the lack of supporting teaching resources provided a challenge for the teachers to provide effective vocabulary instruction for the students. One of the teacher participants, $\mathrm{T} 2$, responded to the interview and revealed that audio transcripts of listening practices were not always provided by the publishers and it turned out to encumber the teachers' load of teaching. She stated,

"Listening is quite difficult to implement. Sometimes from the textbook we bought, we cannot find the audio recording (e.g. CD). So, I tried to look for suitable materials from internet. Hence, sometimes the textbooks are given, the listening materials and the transcripts are 
available there, but there are no audio recordings." (T2, follow up interview).

\section{DISCUSSION}

Technological application utilized to teach vocabulary in the classrooms was taken into account by the EFL teacher participants as one of the supporting factor in vocabulary instruction. Teaching vocabulary is not only a matter of providing word meanings through several teaching strategies, paper-based dictionaries, or other vocabulary textbooks, but it also involves a number of technological devices which are expected to increase the students' vocabulary knowledge. From the interview data, the EFL teacher participants reported that they preferred the use of technology, such as the use of internet, to support their vocabulary instructional practices. The teachers maintained that internet provided with easy-tosearch teaching materials which could effectively and practically implemented in classrooms. Furthermore, they argued that the students would find it easier to learn English word meanings as they used English for real communication with other people in the world through internet. The findings of this study echoed several similarly previous studies which revealed the effectiveness of internet in vocabulary teaching and learning [2] [12] [16] [23] [25] [28] [30] [32] [38] [39] [45] [50] [52] [58].

In addition to students' vocabulary learning, the teachers' responsibility in presenting the materials easily and clearly in the classrooms was seen from their interview data. Most of the participants agreed that technology helped them save time in presenting the lesson and provide the students with attractive teaching media, for example Power point presentation. Several studies reported similar findings [1][3][18][31][35] [37][42][22][44][57]. In their study, [3] found that the students who were exposed to PowerPoint presentations were more successful than those in traditional lectures after the instruction. Moreover, the results of [18] study showed that students exposed to power-point presentations preferred them over the textbook presentations, and she believed that the students were learning better when their attention was captured via highlighting, color, different fonts, and visual effects. What's more, [44] claimed that PowerPoint positively stimulated students' thinking due to its multimedia nature which entailed visual, auditory, and kinesthetic modalities. In addition, most of EFL teachers taught large classes which eventually gave them a challenge in teaching a large number of students. As a consequence, teaching vocabulary via Power point presentations could use the class-time efficiently, made use of learning materials effectively, and worked well with such crowded classrooms [22].

In order to make an efficient vocabulary teaching, some facilities are ideally utilized to support the teaching and learning process. One of the school facilities which is frequently used to support teaching and learning process is language laboratory (language lab). The demand on language labs in teaching English, particularly vocabulary, is due to the effectiveness of language labs to enhance students' vocabulary knowledge [4][15][19][17][51].

However, in some schools, language teaching facilities, such as language labs, are not as accommodating as they are supposed to be. The same thing also happens in some local schools in Samarinda. Based on the interview data, the EFL two teacher participants (T2 and T3) claimed that lack of teaching facilities could be a barrier in teaching and learning process. In the interview, one of them (T2) declared that her school language lab did not function well due to technical problems. Moreover, electricity was also a big concern for the language lab to work properly (T3's case). Even though there were few related studies on this issue, the EFL teachers' perspectives were aligned with some previous studies which revealed that lack of school facilities, considered a contextual factor, was one of the barriers in English language teaching [27][13].

Thus, the teachers maintained that they needed to be more creative and innovative in applying teaching strategies. Despite the less functional language labs in their schools, they implemented the instruction, which was preferably carried out in the language labs, inside the classrooms. From the observation data, it was clearly seen that the EFL teacher participants employed several vocabulary teaching strategies, such as use of picture, word elicitation, translation, synonym, etc., through teaching media such as laptop, LCD and sound speakers for listening practice. As a consequence, the use of audio, visual as well as audio visual supports, such as video, was provided by the teachers in the classrooms as a compensation for not using language labs for language teachnmjing. In other words, the teachers' initiative in utilizing such teaching supports in the classroom shows their decision-making skill, which is enhanced during their professional teaching experiences, for better instructional practices [47].

Furthermore, the necessity of using technology in classroom practice is mostly based on the teachers' beliefs that they needed to provide the students with appropriate teaching materials and resources which might not be equipped in their textbooks. Furthermore, the necessity of using technology in classroom practice is mostly based on the teachers' beliefs that they needed to provide the students with appropriate teaching materials and resources which might not be equipped in their textbooks.

\section{PEDAGOGICAL IMPLICATIONS}

EFL teachers must be equipped with technological knowledge. Teachers' superficial knowledge on the use of technology for teaching was seen from their observed teaching practice where they merely applied very simple technology, such as Power point presentation, in delivering lessons. As a consequence, some training on the use of advanced technology for teachers should be taken into account by the teacher educators, the schools, and even the policy makers. These classroom challenges are aligned with [6][14] who found out that teachers' lack of technological competence which involves lack of hardware, lack of knowledge and skills about 
using computers, lack of training or insufficient training opportunities, lack of teachers' confidence and crowded classrooms were determined as the most important problems faced by the teachers.

Furthermore, from this study result, it is implied that the use of teaching aids is significant to enhance students' vocabulary knowledge. The use of native speaker talks through listening tasks can be used as a medium for learning English in the real language context. By listening to English native speakers, the exposure to English language is higher than the input from the teachers. As a consequence, teaching resources used by the teachers in class are supposed to entail the exposure to the real context of English, not only in listening skills but also all English skills including speaking, reading, and writing, and should be taken into account by not only teachers but also the authorities which are responsible for the supply of learning materials to the schools.

\section{REFERENCES}

[1] Z. Abdellatif, "Exploring students' perceptions of using powerpoint in enhancing their active participation in the EFL classroom action research study," Journal of Literature, Languages and Linguistics, vol. 5, pp. 3639, 2015.

[2] M. K. Agarwal, "Internet-based language learning and teaching," Innovative Info Technologies for Science and Education, vol. 1, no. 8, pp. 3-7, 2010.

[3] M. Akhlaghi, and G. Zareian, "The effect of powerpoint presentation on grammar and vocabulary learning of Iranian pre-university EFL learners," Academic Research International, vol. 6, no. 1, pp. 167-172, 2015.

[4] S. N. S. Al-Hmoud, "Effectiveness of using English lab on English language students' pronunciation at Mu'tah University from the students' perspectives," International Interdisciplinary Journal of Scientific Research, vol. 1, no. 1, pp. 4-94, 2014.

[5] J. P. Allen, R. C. Pianta, A. Gregory, A. Y. Mikami, and J. Lun, "An interaction-based approach to enhancing secondary school instruction and student achievement," Science, vol. 19, pp. 1034-1037, 2011.

[6] A. Asan, "Computer technology awareness by elementary school teachers: A case study from Turkey," Journal of Information Technology Education, vol. 2, pp. 153-164, 2003.

[7] K. Barnes, R. Marateo, and S. Ferris, "Teaching and learning with the net generation," Innovate, vol. 3, no. 4, 2007.

[8] I. Beck, M. McKeown, and L. Kucan, Creating Robust Vocabulary. New York: The Guilford Press, 2008.

[9] J. I. Berne, and C. Blachowicz, "What reading teachers say about vocabulary instruction: Voices from classroom," The Reading Teacher, vol. 62, no. 4, pp. 314-323, 2008.

[10] C. Biancarosa, and C. E. Snow, A Vision for Action and Research in Middle and High School Literacy: A Report to Carnegie Corporation of New York. Washington, DC: Alliance for Excellent Education., 2006.

[11] A. Biemiller, and C. Boote, "An effective method for building meaning vocabulary in primary grades," Journal of Educational Psychology, vol. 98, no. 1, pp. 44-62, 2006.

[12] I. V. Boas, "Process writing and the internet: Blogs and ning networks in the classroom," English Teaching Forum, vol. 49, no. 2, pp. 26-33, 2011.

[13] S. Borg, "Teacher cognition in language teaching: A review of research on what language teachres think, know, believe, and do," Language Teaching, vol. 36, no. 4, pp. 81-109, 2003.

[14] C. Buabeng-Andoh, "Factors influencing teachers' adoption and integration of information and communication technology into teaching: A review of the literature," International Journal of Education and
Development using Information and Communication Technology, vol. 8, no. 1, pp. 136-155, 2012

[15] M. Celce-Murcia, D. Brinton, and J. Goodwin, Teaching Pronunciation: A Reference for Teachers of English to Speakers of Other Languages. New York: Cambridge University Press, 1996.

[16] G. M. Chinner, "Call me...maybe: A framework for integrating the internet into ELT," English Teaching Forum, vol. 1, pp. 2-13, 2014.

[17] R. Chrisman, Testing speaking. 1999. Retrieved from http://teflchina.org, on 30 August, 2017

[18] G. Corbeil, "Can powerpoint presentations effectively replace text-books and blackboards for teaching grammar? do students find them an effective learning tool?," CALICO Journal, vol. 24, no. 3, pp. 631-656, 2007.

[19] E. J. Cruz Rondón, and L. F. Velasco Vera, "Understanding the role of teaching materials in a beginners' level English as a foreign language course: A case study," PROFILE Issues in Teachers' Professional Development, vol. 18, no. 2, pp. 125-137, 2016.

[20] A. E. Cunningham, and K. E. Stanovich, "What reading does for the mind," American Educator, vol. 22, no. 1, pp. 8-15, 1998.

[21] B. Dalton, and D. L. Grisham, "eVoc Strategies: 10 ways to use technology to build vocabulary," The Reading Teacher, vol. 64, pp. 306-317, 2011.

[22] M. A. de Leon Perez and D. C. Garcia de Angulo, "The effectiveness of using powerpoint for teaching vocabulary to increase the vocabulary knowledge for the reading skill, among the students of the intermediate intensive English I of semester II at the foreign language department in the university of El Salvador," Unpublished thesis: University of El Salvador, 2013.

[23] J. Egbert, O. Akasha, L. Huff, and H. Lee, "Moving forward: Anecdotes and evidence guiding the next generation of CALL," International Journal of Computer-Assisted Language Learning and Teaching, vol. 1, no. 1, pp. 1-15, 2011.

[24] E. Ely, P. C. Pullen, M. J. Kennedy, S. E. Hirsch, and M. C. Williams, "Use of instructional technology to improve teacher candidate knowledge of vocabulary instruction," Computers \& Education, vol. 75, pp. 44-52, 2014.

[25] U. Felix, "The unreasonable effectiveness of CALL: What have we learned in two decades of research?," ReCALL, vol. 20, no. 2, pp. 141$161,2008$.

[26] R. C. Gardner, Social psychology and second language learning: The role of attitudes and motivation. London, GB: Edward Arnold, 1985.

[27] M. R. Gerami, and N. Noordin, "Teacher cognition in foreign language vocabulary teaching: A study of Iranian high school EFL teachers," Theory and Practice in Language Studies, vol. 3, no. 9, pp. 1531-1545, 2013.

[28] D. Gonzalez, and R. St. Louis, "Promoting learner autonomy with Web 2.0 tools," in Autonomy in Language Learning: Opening a Can of Worms, C. J. Everhard, J. Mynard, and R. Smith, Eds, Canterbury, Reino Unido: IATEFL, 2012, pp. 238-247.

[29] M. F. Graves and S. Watts- Taffe, "For the love of words: Fostering word consciousness in young readers," The Reading Teacher, vol. 62, no. 3, pp. 185-193, 2008.

[30] M. Hismanoglu, "Teaching word stress to Turkish EFL (English as a Foreign Language) learners through internet-based video lessons," USChina Education Review, vol. 1, pp. 26-40, 2012.

[31] B. G. Ilter, "Effect of technology on motivation in EFL classrooms," Turkish Online Journal of Distance Education, vol. 10, no. 4, Art. 9, 2009.

[32] P. Isola, J. Xiao, A. Torralba, and A. Oliva, "What makes an image memorable?," IEEE Conference on Computer Vision and Pattern Recognition (CVPR), pp. 145-152, 2011.

[33] J. Johnston, and L. T. Barker, Assessing the Impact of Technology in Teaching and Learning: A Sourcebook for Evaluators. University of Michigan, USA: Institute for Social Research, Department of Education, 2002.

[34] D. H. Jonassen, and T. C. Reeves, Learning with technology: Using computers as cognitive tools, in Handbook of Research for Educational 
Communications and Technology, D. H. Jonassen, Ed, 1996, pp. 693719. Retrieved from: http://www.aect.org/edtech/ed1/24/index.html

[35] F. Kaptan, and H. Korkmaz, "The effects of co-operative problem solving approach on creativity in science course," Journal of Qafqaz, vol. 9, no. 143-150, 2002.

[36] S. Kvale, Interviews: An Introduction to Qualitative Research Interviewing. Thousand Oaks, CA: Sage, 1996.

[37] F. S. Lari, "The impact of using powerpoint presentations on students' learning and motivation in secondary schools," Procedia - Social and Behavioral Sciences, vol. 98, pp. 1672 - 1677, 2014.

[38] J. W. LeLoup, and R. Ponterio, "Second language acquisition and technology: A review of the research," CAL Digest, 2003. Retrieved from: www.cal.org/resources/digest/0311leloup.html

[39] R. E. Mayer, Multimedia Learning (2nd ed). Cambridge: CUP, 2009.

[40] M. B. Miles, and A. M. Huberman, Qualitative Data Analysis (2 ${ }^{\text {nd }}$ ed.). Thousand Oaks: Sage, 1994.

[41] W. E. Nagy, and P. A. Herman, "Incidental vs. instructional approaches to increasing reading vocabulary," Educational Perspectives, vol. 23, no. 1, pp. 16-21, 1985.

[42] T. T. Nam, and L. Q. Trinh, "Powerpoint as a potential tool to learners' vocabulary retention," Journal on English Language Teaching, vol. 21, no. 41, pp. 15-22, 2012.

[43] D. G. Oblinger, and J. L. Oblinger, Educating the Net Generation. EDUCAUSE. 2005. Retrieved from http://net.educause.edu/ir/library/pdf/pub7101.pdf

[44] A. Oommen, "Teaching English as a global language in smart classrooms with powerpoint presentation," English Language Teaching, vol. 5, no. 12, 54-61, 2012.

[45] A. Paivio, Mind and Its Evolution: A Dual Coding Theoretical Approach. Mahwah, NJ: Lawrence Erlbaum, 2006.

[46] R. C. Pianta, A. J. Mashburn, J. T. Downer, B. K. Hamre, and L. Justice, "Effects of web-mediated professional development resources on teacher-child interactions in prekindergarten classrooms," Early Childhood Research Quarterly, vol. 23, pp. 431-451, 2008.

[47] V. Prachagool, P. Nuangchalerm, G. Subramaniam, and J. Dostál, "Pedagogical decision making through the lens of teacher preparation program," Journal for the Education of Gifted Young Scientists, vol. 4, no. 1 , pp. 41-52, 2016

[48] M. Prensky, "Digital natives, digital immigrants," On the Horizon, vol 9, no. 5, 2001. Retrieved from http://www.marcprensky.com/writing/

[49] [3] T. C. Reeves, The Impact of Media and Technology in Schools. A Research Report prepared for The Bertelsmann Foundation, The University of Georgia, USA, 1998

[50] H. Reinders, "20 ideas for using mobile phones in the language classroom,” English Teaching Forum, vol. 46, no. 3, pp. 20-25, 2010

[51] W. M. Rivers, Teaching Foreign Language Skills. Chicago: University of Chicago Press, 1970.

[52] S. N. Sad, "Using mobile phone technology in the EFL class," English Teaching Forum, vol. 46, no. 4, pp. 34-39, 2008.

[53] R. Santagata, "Designing video-based professional development for mathematics teachers in low-performing schools," Journal of Teacher Education, vol. 60, pp. 38-51, 2009.

[54] J. Schacter, The Impact of Education Technology on Student Achievement: What the Most Current Research Has to Say. California, USA: Milken Exchange on Education Technology, 1999.

[55] T. M. Segler, Second Language Vocabulary Acquisition and Learning Strategies in ICALL Environments, 2001. Retrieved from: http://www.tandfonline.com/doi/abs/10.1076/call.15.4.409.8272\#.UgQi GcuI7Mw

[56] P. Sharma, and B. Barrett, Blended Learning: Using Technology in and beyond the Language Classroom. Oxford: Macmillan Publishers Ltd., 2007.

[57] P. K. Tao, "Confronting students with multiple solutions to qualitative physic problems," Physics Education, vol. 36, no. 2, pp. 135-139, 2001.

[58] C. M. Tardy, "Writing for the world: Wikipedia as an introduction to academic writing," English Teaching Forum, vol. 48, no. 1, pp. 12-19, 2010 .

[59] M. J. Wang, "Using multimodal presentation software and peer group Discussion in learning English as a second language," Australasian Journal of Educational Technology, vol. 27, no. 6, pp. 907-923, 2011. 